\title{
Multiculturalism and the Fetishism of Difference*
}

\author{
Colin Mooers Ryerson University
}

Cette communication trace les tractations internes de la dualité du travail humain au sein du capitalisme, la manière dont les idéologies de race et de sexe du capitalisme concrétisent « l'autre », ainsi que les formes fétichistes de la " différence » exprimées dans des notions libérales de citoyenneté multiculturelle. Une telle critique immanente permet d'éclairer un des paradoxes au cœur de la « diversité » : comment le processus même de la reconnaissance des différences ethniques et culturelles du multiculturalisme endigue et déforme les relations sociales concrètes du capitalisme. L'idéologie fétichiste de la citoyenneté multiculturelle devrait être perçue comme une " forme de compromis » qui déforme à la fois les relations sociales et mène à un affranchissement potentiel au-delà de lui-même.

This paper charts the internal mediations between the duality of human labour under capitalism, the way in which capitalism embodies its 'others' through ideologies of race and gender, and the fetishistic forms of 'difference' expressed in liberal notions of multicultural citizenship. Such an immanent critique helps to explain one of the central paradoxes of 'diversity': how in the very process of recognizing ethnic and cultural differences, multiculturalism also occludes and distorts capitalism's concrete social relations. The fetishistic ideology of multicultural citizenship should be understood as a 'compromise formation' which both distorts social relations and gestures toward an emancipatory potential beyond itself.

* I would like to thank David McNally, Alan Sears and the anonymous reviewers of this journal for their comments on earlier drafts of this paper. 


\section{Multiculturalism and the Fetishism of Difference}

The form of abstract citizenship peculiar to liberal capitalist society has not dealt particularly well with what has come to be called issues of 'difference'. At the core of this conception of citizenship, after all, is the idea that the concrete particularities of individuals and groups needed to be left behind - abstracted from - in the interests of universal personhood. Not surprisingly, those who have been excluded from the capitalist public sphere on the basis of race, gender or sexual orientation have found this conception of citizenship wanting. The advent of multicultural citizenship in recent years might appear to go some way toward resolving this problem, at least as far as racialized minorities are concerned, by now including issues of cultural and ethnic difference within its ambit. The apparent inclusivity of multicultural citizenship may indeed represent, as one commentator recently put it, "the highest stage of liberalism" (Sears, 2003:141). Any acknowledgment which oppressed and excluded groups receive in the public and political spheres is of course an important achievement, especially when recognition has been forced upon the state by popular struggles in the form of what Himani Bannerji has called "multiculturalism from below" (Bannerji, 2000: 22).

There are, however, plenty of reasons to be wary of state-sponsored forms of multiculturalism as well as the increasingly common market infatuation with issues of diversity. As I will argue at length below, the reified forms of ethnicity and 'difference', which are the staples of multicultural discourse and practice, are in fact entirely congruent with the fetishistic social forms abundant in contemporary capitalism. "Difference," as Terry Eagleton has recently observed, has become "the new catch-cry in a world increasingly subject to the same indignities of starvation and disease, cloned cities, deadly weapons and CNN television" (Eagleton, 2003: 46). But it is not just commodified imagery and life style which has allied multiculturalism to globalizing capitalism. I will argue that the very form of multicultural citizenship needs to be understood within the context of a dialectics of the body rooted in the duality of human labour under capitalism. This duality is fundamental to both the racialization and gendering of concrete bodies and to occlusion of the lived experience of concrete difference. This elision of race and gender becomes all the more difficult to trace since liberal multiculturalism substitutes the appearance of plurality and diversity for its very opposite: in place of concrete social relations it substitutes abstract and reified forms of 'difference'.

The gist of my argument runs as follows: bourgeois society establishes a dialectics of embodiment which simultaneously abstracts from the concrete, sensuous, embodied aspects of human labour at the same time as it over-embodies the subjects of labour with ideologies of race, gender and sexuality. In the sphere of exchange, where all concrete markers of labour have been extinguished and where capital and labour confront each other as apparent equal buyers and sellers, capital appears sublimely indifferent to 
difference. Thus arise the material preconditions for liberal notions of abstract citizenship and the basis for its fetishistic character, masking as it does class inequality beneath the formal appearance of universal equality. Multicultural citizenship appears to overcome the abstract generality of the liberal model through the validation of concrete cultural and ethnic differences. However, the reified forms of ethnicity and visibility which it establishes as the markers of recognition are as equally abstract and fetishistic. Indeed, multicultural citizenship goes one step further than the classical liberal model by more effectively obscuring the relations of power upon which difference is constructed.

Such a framework, I argue, helps to resolve one of the central paradoxes of 'diversity' (Bannerji, 2000): how it is that in the very act of recognizing 'difference', the concrete experience of race and gender seems to be effaced and occluded. My intention is not to conflate race or gender with class, nor is it to attenuate the myriad expressions which race and other forms of oppression have assumed historically. Rather, it is to chart the internal mediations that exist between the duality of human labour under capitalism, the way in which capitalism embodies its 'others' and the fetishistic forms of 'difference' expressed in liberal multiculturalism.

In section one, I explore the emergence of the discourse of multiculturalism as an attempt to manage the migration of labour in advanced capitalist societies and only secondarily as a response to calls for greater recognition of diversity. The aim here is not to present an exhaustive account of multicultural policy, but rather to frame its 'cultural logic' within the broader parameters of capitalist processes of commodification. Section two examines the dynamics of race, class and gender under capitalism and how this interplay is reflected in the lived experience of concrete social relations. Section three traces the lineaments of capitalism's contradictory dialectics of embodiment through the prism of Marx's distinction between concrete and abstract labour. The opposition between concrete and abstract labour, I argue in the final section, is key to understanding not only the myriad forms of racism and sexism which permeate the bourgeois public sphere, but also the reified and fetishistic forms of multicultural citizenship under contemporary capitalism.

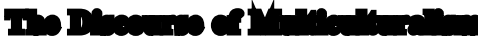

The discourse of multiculturalism is of a relatively recent vintage, coming into general usage in the early 1990s (Bannerji, 2000). Multiculturalism has attained its widest popularity in Australia and Canada, and only latterly and more unevenly in countries such as Great Britain and the United States. In Europe, liberal multiculturalism - or what is called 'harmonization' - has found less secure footing. The French government's moves to ban the wearing of head scarves by Muslim women in state-run schools - which has also been taken up in Italy - demonstrates just how limited and expendable liberal tolerance can be when there is a perceived threat to dominant cultural values. Nevertheless, 


\section{Multiculturalism and the Fetishism of Difference}

multiculturalism has become official state policy in some states as a means of coping with successive waves of immigration, especially in the former white-settler states like Canada and Australia, where the importation of labour has been crucial to capitalist development. By the 1980s "diversity management" had become particularly acute as labour mobility increased and more and more labour was being drawn to the metropolitan centres from various parts of the Third World (Davis, quoted in Bannerji, 2000: 27).

In Canada, multiculturalism emerged in the 1970s and 80s in response to new waves of immigration from non-white countries of the Third World, a resurgent nationalist movement in Quebec, and the first stirrings of aboriginal demands for self-government. It became official state policy under the Trudeau government in 1971. This policy was the pure lain concoction of the state as it sought means to cope with the social and economic inequalities associated with the influx of a low-wage immigrant population. There were very few voices in these immigrant communities that called on the government to initiate a policy of multiculturalism. Their main concerns had to do with racism, low paying jobs, affordable housing and other problems associated with settlement in a new country (Bannerji, 2000).

While the policy marked a new attempt to construct a more inclusive liberal polity centred around notions of cultural difference, it is important not to lose sight of the fact that it was also in many respects an extension and broadening of the monoculturalism which characterized Canadian immigration policy for most of its history (Sears, 2003). The preference given to 'white-settler' immigrants from Britain and Ireland was gradually broadened to include immigrants from other parts of northern and eventually southern Europe. This widening of the definition of 'whiteness', however, did not unseat the privileged position of the original British colonists. Canadian identity was still anchored in a racialized hierarchy (Day, 2000). Monoculturalism became an obstacle in the 1960s and 1970 s as non-British immigrants began to predominate. Multiculturalism became part of the official ideology of the Canadian state which portrayed Canada as an open, tolerant and inclusive society.

Multicultural policy, like the earlier policies of bilingualism and biculturalism, also served to culturalize and ethnicize national politics in a way that distracted attention away from class cleavages, regional disparities and other structural inequalities of capitalism. The celebration of 'ethnic diversity' in the form of cultural festivals, food fairs, religious ceremonies, and a host of 'invented traditions' now receives official state sponsorship. Meanwhile, the language of anti-racism was pushed even further to the margins, through the promotion of the new official discourse of multiculturalism. Thus, from its beginnings, multiculturalism was more a manufactured affair which spoke in the first instance to the needs of the state than it was a response to demands coming from immigrant communities 
themselves:

\begin{abstract}
Multiculturalism was... not a demand from below, but an ideological elaboration from above in which the third world immigrants found themselves. This was an apparatus which rearranged questions of social justice, of unemployment and racism, into issues of cultural diversity and focused on symbols of religion, and so-called tradition. Thus immigrants were ethnicized, culturalized and mapped into traditionallethnic communities. Gradually, a political and administrative framework came into being where structural inequalities could be less and less seen or spoken about (Bannerji, 2000: 44-45).
\end{abstract}

Australia adopted multiculturalism as official policy in the 1970s. Aborigines were simply folded into the multicultural mix which included Germans, Chinese, Vietnamese, Pacificislanders and the white-settler groups which had colonized the country in the nineteenth century. In similar fashion, the Australian state also fostered a rhetoric of multiculturalism which served to occlude the capitalist roots of its immigration policies. Like Canada, the Australian economy had always depended on immigrant labour. Multiculturalism was simply the discourse which the state adopted for coping with the problems associated with the importation of cheap labour as well as being a convenient way of erasing the history of capitalist exploitation from the popular imagination (Koundoura, 1998).

These sanitized versions of multiculturalism have served to reify ethnicity in ways that are particularly functional to commodification. Thus, market depictions of cultural difference have become common in advertising campaigns. Diversity has become part of the armature of the savvy marketer. ${ }^{1}$ Transnational corporations have quickly learned that if the faces depicted in advertisements and the corporate personnel who sell their products look like those in the markets they are trying to penetrate, this can be translated into a market advantage. As Naomi Klein observes in No Logo:

Corporations were selling most aggressively the idea of a global market, a kaleidoscope of multi-ethnic faces blending into one another: rasta braids, pink hair, henna hand painting, piercing and tattoos, a few national flags, flashes of foreign street signs, Cantonese and Arabic lettering and a sprinkling of English words, all over the layer samplings of electronica. Nationality, language, ethnicity, religion, and politics were all reduced to the most colourful, exotic, commodity accessories, converging to assure us that there is never an us and them, but simply one giant consumer we (Klein, 2000:120).

\footnotetext{
${ }^{1}$ Gage Avrill argues that "corporations are engaging in an emergent corporate strategy to penetrate resistant foreign markets by playing to thin or superficial version of cultural differences as a means of establishing globally uniform habits of consumption" (Avrill, 1996: 203). The business and marketing press has discovered the profit to be had from ethno-cultural marketing. See also Halter (2000) and Costa (1995). Diversity marketing tips and identity politics are combined on the website: http://www.diversity.com.html. Thanks to Tanner Mirrlees for bringing these references to my attention.
} 


\title{
Multiculturalism and the Fetishism of Difference
}

Deliberate policies of commodification have been adopted to bolster consumption and cultural tourism within ethnic enclaves. This "folkloric spectacle of diverse cultures" (Banerjee and Linstead 2001: 705) has served to promote an ideology of benign otherness in which the exotica of foreign cultures can be enjoyed without jeopardizing the dominant culture. In this shift, the evanescent politics of race give way images of pluralistic harmony. ${ }^{2}$

It is hard not to notice the convergence of commodified ethnicity with its superficial reduction of difference to the bland sameness of the 'consumer we' and the formal equality of liberal multiculturalism which reduces and negates real class and racial inequalities. Liberal multiculturalism thus effects "the experience of the Other deprived of its Otherness" (Zizek, 2002: 11). In this way, the appearance of diversity and variety can be sustained while global capitalism increasingly homogenizes differences. The domestication of otherness thus becomes part of a larger process in which culture is deployed in the interests of commodification. In this sense, the visibility of "visible minorities" becomes a selling point in a culture thoroughly saturated by the commodification of visual images (Jameson, 1998: 111). As Jameson reminds us, the globalization of capitalism has greatly attenuated cultural difference thereby easing the acceptance of 'alien' cultures within the metropolitan centres:

\begin{abstract}
We... need to take into account the possibility that the various politics of difference - the differences inherent in the various politics of "group identity" have been made possible only by the tendential leveling of social identity generated by consumer society; and to entertain the hypothesis that a cultural politics of difference becomes feasible only when the great and forbidding categories of classical Otherness have been substantially weakened by "modernization" (so that current neoethnicities may be distinct from the classical kind as neoracism is from classical racism) (Jameson as quoted in San Juan, 2002: 159).
\end{abstract}

This has led some to see the discourse of multiculturalism as a kind of substitute language - a 'cultural logic' - for talking about its opposite, namely the unprecedented homogenization of the world system. Thus, Zizek (1997a: 46) concludes that "critical energy has found a substitute outlet in fighting for cultural differences which leave the basic homogeneity of the capitalist system intact." The problem with this discourse is that,

any notion of "vertical" antagonism that cuts through the social body is strictly censored, substituted by and/or translated into the wholly different notion of "horizontal" differences with which we have to learn to live because they

\footnotetext{
${ }^{2}$ As Bannerji (2000: 32) observes: "the concept of race lost its hard edges of criticality, class disappeared entirely, and colour gave a feeling of brightness, brilliance or vividness, of a celebration of difference which was disconnected from social relations of power, but instead perceived as diversify, as existing socio-cultural ontologies or facts."
} 


\section{complement each other. The underlying ontological vision here is that of the irreducible plurality of particular constellations, each of them multiple and displaced in itself, which can never be subsumed under any universal container (Zizek, 2002: 65).}

Those who reify cultural difference often draw on the same fund of epistemological and ontological tropes as the racist and xenophobic ideologies that they oppose. Romantic and anti-Enlightenment notions of trans-historical authenticity and primordial identity are linked with exoticist conceptions of the Other. On this view, cultural discourses are selfsubsistent and incommensurable. This collapse of knowing into being, and the consequent denial of transcultural communication, are just as much a part of the conceptual armature of Hindu communalists, Islamic fundamentalists and Serbian nationalists as they are cosmopolitan postmodernists and liberal mulcticulturalists (Al-Azmeh, 1996). ${ }^{3}$ If the latter have settled on more domesticated versions of otherness than the former, this may only reflect their generally more positive view of the jouissance associated with the commodified identities available in the advanced capitalist world.

If the reified forms of multicultural discourse have indeed become a kind of 'substitute language' for talking about other, less obvious forms of difference such as those of class, then we need to understand more precisely how capitalism reconstructs race, gender and class relations such that it foregrounds markers of race and gender difference in the labour process at the same time as it covers its own tracks by masking these same processes.

The reification of culture has helped to fuel not only more recent forms of "differentialist" or cultural racism (Taguieff, 2001), which asserts an unbridgeable gap between self and other based on cultural distinctions, but also older forms of racism based on phenotypical characteristics. In Australia, for example, it has led to the revival of populist racism in the form of the 'One Nation' party of Pauline Hansen which plays on fears of crime-ridden ethnic ghettos. As Holton observes, "The shallowness of official multicultural discourses on cultural difference has thereby created a two-edged sword. Recognition of difference may be a first step towards a cultural democracy, yet it may equally reinforce cultural stereotypes that reinforce racism and prejudice" (Holton, 2000: 197). In Canada, the "we" of English Canadian identity is

${ }^{3}$ Collette Guillaumin argues that 'difference' talk has become the polite form for 'race' talk: "This is because difference has come to inherit all the connotations relating to the specificity of human groups which in the old days were carried by notions of race. It is true that the idea of difference is an attempt to get away from the imperative of physical naturality imposed by race and in that sense its aim is certainly to break down the rigidity of the racist system of thought. But as the same time it attracts those who persist in thinking in racist terms, but no longer use the word 'race'." (Guillaumin, 1999: 43) Therefore, she concludes, 'difference' talk, however well-intentioned, must be rejected: "it is a question of facts, not one of intentions or opinions, as some people would have us believe" (Guillaumin, 1999: 45). 


\title{
Multiculturalism and the Fetishism of Difference
}

\begin{abstract}
an essentialized version of a colonial European turned into Canadian and the subject or agent of Canadian nationalism...the Canadian "we" does not reside in language, religion or other aspects of culture, but rather in the European/North American physical origin - the body and the colour of skin. Colour of skin is elevated here beyond its contingent status and becomes an essential quality called whiteness, and this becomes the ideological signifier of a unified non-diversity (Bannerji, 2000:42).
\end{abstract}

In the United States, the long-standing racialization of Blacks subsists and intersects with class divisions and newer forms of cultural racism. Aihwa Ong points out how the racialization of class results in different outcomes for Chinese refugees and business people. The kind of treatment received by these groups is dependent on how they are 'ethnicized' along the "black-white spectrum" (Ong, 1999: 286) Having learned that imitating the habits of their white neighbours is likely to bring greater acceptance by the white population, Chinese investors have elected to become as ethnically 'white' as possible, an option not open to the poorer refugee populations. Even this strategy has provoked a rise in random attacks on Asians.

The complexity of these examples suggests that racism is not a static but rather a fluid, contradictory and multidimensional phenomenon. Although it would be a mistake to reduce racism to class dynamics, it is just as important not to lose sight of how closely allied these processes have been historically. Like the kindred ideologies of nationalism and sexism, modern forms of racism are deeply imbricated with the capitalist processes of colonialism, capital accumulation, and the migration of labour (Miles and Brown, 2003). As Harvey reminds us, "Class, race and gender, and all manner of other distinctions are marked upon the human body by virtue of the different socio-economic processes that do their work upon the body" (Harvey, 2000: 99).

In principle, there is nothing in the structure of capitalist relations which makes racism a necessary feature of the system. Indeed, it could be argued that the tendency of capitalism is to equalize the labour it exploits for the simple reason that its primary interest is in exploitable labour and therefore does not particularly care what its gender or skin colour happens to be. Modern biological racism was the product of two conflicting tendencies. On the one hand, the advent of free wage labour was one of the fundamental building blocks of political democracy. The doctrine espoused by all of the major liberal theorists starts from the premise that human beings are born equal. On the other hand, colonial expansion and the slave trade had underwritten early capitalist accumulation to a considerable degree. The dilemma is obvious: how was it possible to justify the enslavement of millions and remain consistent with the principles of liberal theory? This was precisely the question posed by Toussaint L'Ouverture and the slave rebellion in Haiti that erupted in the wake of the French Revolution. To the cries of 'Liberte, Egalite, 
Fraternite' echoing from the revolutionary assemblies in Paris, Toussaint replied: "I want liberty and equality in San Domingo" (Blackburn, 1988: 218). It was arguably this contradiction that produced the nineteenth century ideology of racial inferiority, a doctrine which allowed for the cohabitation of the liberal ideals of formal equality and freedom among 'equals' and racial inequality and unfreedom for those considered less than fully human. But as Wood (1995: 296) points out, "it was precisely the structural pressure against extra-economic difference which made it necessary to justify slavery by excluding slaves from the human race, making them non-persons standing outside the normal universe of freedom and equality."

But capitalism also has an uncanny ability to absorb forms of oppression inherited from the past, which it interweaves with newer configurations of race and gender to produce baroque ideologies of the body. With the rise of what Anne McClintock has called "commodity imperialism" in the late nineteenth century:

the rhetoric of race was used to invent distinctions between what we would now call classes...the rhetoric of gender was used to make increasingly refined distinctions among the races. The White race was figured as the male of the species and the black race as the female. Similarly, the rhetoric of class was used to inscribe minute and subtle distinctions between other races (McClintock, 1995: 54-55).

The circulation of variable capital in the form of wage labour reconstructs race and gender in specifically capitalist ways (Harvey, 2000). There exists an "interplay between the social relations of production and the racialization process" (Miles and Torres, 1999: 33). Race is a signifying practice that permits the construction of racial hierarchies and divisions within the labour process. As San Juan (2003: 13-14) observes:

The capitalist mode of production articulated "race" with class in a peculiar way... In the capitalist development of U.S. society, African, Mexican, and Asian bodies - more precisely, their labor power and its reproductive efficacy were colonized and racialized.... "Race" is thus constructed out of raw materials furnished by class relations, the history of class conflicts, and the vicissitudes of colonial/capitalist expansion and the building of imperial hegemony. It is dialectically accented and operationalized not just to differentiate the price of wage labor within and outside the territory of the metropolitan power, but also to reproduce relations of domination-subordination invested with an aura of naturality and fatality. The refunctioning of physical or cultural traits as ideological and political signifiers of class identity reifies social relations. Such "racial" markers enter the field of the alienated labor process concealing the artificial nature of meanings and norms, and essentializing or naturalizing historical traditions and values which are contingent on mutable circumstances. 


\section{Multiculturalism and the Fetishism of Difference}

If we are to speak of class concretely and not as an abstraction, then class is always raced and gendered: "it cannot be understood independently of concrete social relations which specify the concretizing forms of difference" (Bannerji,1995: 34). Concrete labour is embodied labour in the fullest sense of the term. It is at the point of production where concrete bodies are most immediately and sentiently present and where the realities of race and gender have a palpable presence. It is here that the conjunction of class, race and gender becomes a lived experience, for it is here that specific labours are bound up with specific groups of individuals. And, it is here that the myriad humiliations and degradations of racism and sexism are meted out: scapegoating, targeting, excessive monitoring, marginalization, infantilization, segregation, blaming the victim and tokenism (Das Gupta, 1996: 35-40).

But capitalism is particularly adept at masking these relations. Below I discuss the processes through which capitalism occludes its underlying relations of exploitation by means of the fetishism and reification of commodity relations. What I attempt to show is that the effacement of concrete, embodied labours has much to do with the denial of the lived experience of race and gender under capitalism. At the same time, these same fetishistic relations establish the conditions for their apparent opposite: in place of relations of exploitation, oppression and exclusion we are presented with the appearance of an inclusive public sphere founded on principles of multicultural tolerance.

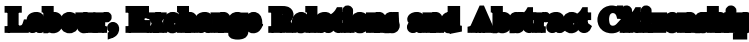

Social relations under capitalism have an inverted 'topsy-turvy' character identified by Marx with the commodity form of labour. In capitalism there is an inversion of the relation between people and things such that things become subjectified and people become objectified. Thus, value, money and capital are 'spiritualized', to magically increase themselves independently of human intervention. Human beings, on the other hand, are objectified as an instrument of the production process. In this sense, capitalism is just as much haunted by ghosts, spectres and phantoms as any precapitalist society. In precapitalist societies something of the spirit of the person is thought to be transferred to the artifact; under capitalism just the opposite occurs; the embodied 'spirit' of the worker is exorcized from the object while the commodity is simultaneously re-animated with "supra-sensible" value (Marx, 1977: 165). This is the fundamental contrast between worlds where use-value and those where exchange-value predominates. By spiritualizing things and objectifying people, the commodity form "inscribes immateriality as the defining feature of capitalism" (Stallybrass, 1998: 184). At the same time, it strips artifacts of the history, memory and desire with which concrete embodied labours invest them, capitalism refashions them into transcendental values - the spectral embodiments of appropriated labour - set free in phantom-form to roam the world. ${ }^{4}$ 
At the heart of this process is the duality of human labour under capitalism. Human labour is both concrete, sensuous, embodied, and subjective and abstract, quantified, and measurable; it is both use-value and exchange-value at the same time. This duality is not harmonious but rather antagonistic. Abstract labour in the form of money is not the selfexpression of concrete labour but it opposite. Abstract labour is alienated labour, labour which stands over and against the human labours which produced it; it is in fact the negation of concrete labour. Things, like the labour which produces them, have become commodities and as such have become severed from their origins in human labour, now circulating as pure quanta of human labour in the abstract form of money. These labours appear now only in the reified form of commodities and money, as alien objects which betray nothing of their origins.

The opposition between concrete and abstract labour needs also to be understood in terms of an opposition in life-projects (McNally, 2004). Commodity fetishism is above all a displacement of meaning from the level of concrete, lived experience of labour to that of the abstract and fetishistic forms of money and capital. "All reification is a forgetting" (Horkheimer and Adorno, 1972: 230). Capitalism would have us believe that it is selfsubsistent and self-positing, capable of producing value wholly from within itself without the aid of human labour. As such, it attempts to transform every trace of concrete labour into abstract, monetized forms. But just as consistently, capital comes up against the brute fact of living labour which cannot be reproduced from within the circuit of capital. "Capital as a whole," as Michael Lebowitz has observed, "does not...include within it that which is a 'necessary condition for the reproduction of capital' - the maintenance and reproduction of the working class... capital as a whole must posit the wage-labourer outside it in order to exist as such...it is necessary to consider the wage-labourer as she exists outside capital" (Lebowitz, 1992: 48-49). Wage-labour has its own telos and logic of reproduction separate from that of capital. Workers are constantly forced into struggle to assert their own needs and life-projects against the imperatives of capital. ${ }^{5}$

\footnotetext{
${ }^{4}$ As Michael Taussig (1993: 22-23) observes: "We need to note...that as the commodity passes through and is held by the exchange-value arc of the market circuit where general equivalence rules the roost, where all particularity and sensuousity is meat-grinded into abstract identity and the homogeneous substance of quantifiable money-value, the commodity yet conceals in its innermost being not only the mysteries of the socially constructed nature of value and price, but also all its particulate sensuousity - and this subtle interaction of sensuous perceptibility and imperceptibility accounts for the fetish quality, the animism and spiritual glow of commodities..."

${ }^{5}$ As Lebowitz (1992: 146-49) notes: "The struggles of workers to satisfy their many-sided needs are thus struggles against the position of capital as mediator within society. They are class struggles struggles of those who are compelled to sell their labour-power to satisfy needs; and they are struggles against the results of capital's ownership of the products of labour (which derives from its purchase of labour-power). Rather than directed against any particular capitals, they are directed against the power of capital as a whole... only the struggle of workers as their own mediator; only this provides workers with a sense of themselves as the producers of social wealth."
} 


\section{Multiculturalism and the Fetishism of Difference}

A similar duality of life-projects and meaning-making is at work in the antagonistic meanings which are generated by the fetishistic forms of citizenship and the racializing processes of capitalism. As concrete labour is transformed into abstract social labour, concrete bodies are left behind and their labours effaced. In performing this abstraction capital obscures its own racializing operations. That is why, at the moment of exchange and circulation, capital appears to be blind to race and gender, and the capitalist and worker confront each other as apparent equals. Money, as the congealed form of abstract labour, conceals the underlying inequality between capitalist and worker and presents that relation instead as "a very Eden of the innate rights of Man" (Marx, 1977: 280). The sphere of circulation and exchange represents the moment of capital's indifference to difference: its only interest is in the extraction of surplus-value and not the social groups which produce it. For Marx, the sphere of exchange and circulation where the worker and capitalist confront each other not as exploiter and exploited but as equal buyers and sellers, expresses "all the mystifications of the capitalist mode of production, all capitalism's illusions about freedom ... [which] have as their basis the form of appearance... which makes the actual relation the invisible opposite of that relation" (Marx, 1977: 680). What is 'mystified' and effaced is the fact that capital does in fact assign unequal values to the labour of different human subjects; differential values - most clearly expressed in differential wage rates - are assigned to the commodified labour of racialized and gendered subjects.

The moment of exchange is thus the material basis for the fetishistic form of bourgeois citizenship. As Werner Bonefeld has argued, there exists a homology between the moneyform and the form of abstract citizenship: "Money represents the standardization of individuals as abstract citizens... Money is the incarnation of liberty, of private property. It represents the liberty of individualized property owners, their equality and freedom" (Bonefeld, 1995: 187-88). Thus, a kind of juridic fetishism compliments the economic fetishism of money. The ownership of private property (including the worker's property in his or her own labour), contractual relations, equality before the law and the state which appear to be the result of human nature or disinterested reason, are best understood as mediated forms of capitalist relations of production. (Mooers; 2001; Fine 1986). ${ }^{6}$ Just as the commodity form conceals the human labours which went into its production, so too does bourgeois citizenship obscure the class antagonisms and racial and gender exclusions which lie below its surface.

\section{Ixanengt}

The opposition between concrete and abstract labour and the duality of meaning-making and life-projects which it sets up, also helps us to map the disjunction between the lived experience of raced and gendered bodies at the level of concrete social relations and how

\footnotetext{
${ }^{6}$ For an extended discussion of law and the state as forms of capitalist social relations, see Simon Clarke (1991); Werner Bonefeld, Richard Gunn and Kosmas Psychopedis (1992; 1995); and John Holloway (2002).
} 
that experience is elided in the liberal discourse of multicultural citizenship. In capitalist society human labour is seen as the product of non-bourgeois others. Bourgeois society is characterized by "its othering of the body and its embodying of others" (McNally, 2001: 4). The effacement of concrete bodily labours has produced a dialectic of embodiment and over-embodiment such that the reproductive labours of women (in both the form of domestic and procreative labour), the forced and sweated labours of the colonized and exploited, have all been consigned to regions beyond the public sphere. Reduced to their bodies, these groups have been sexualized as mothers and fantasy objects or as racialized subjects on whose bodies are inscribed discourses of animal and sexual desire. Labouring bodies of all sorts are effaced in 'grand narrative' of bourgeois society while its cultural achievements are spiritualized as the accomplishments of great thinkers and statesmen.

The classical bourgeois public sphere, as feminist and anti-racist theorists have asserted, was conceived as essentially white and masculine; it implicitly assumed the bourgeois male as the universal class (Fraser, 1996). Its presupposition, in other words, entailed the exclusion of women, the working class and racialized others who did not correspond to the bourgeois masculine ideal. If the public sphere was the realm of abstract generality in which concrete particularities were to be left behind, the private sphere was conceived as "the realm of affectivity, affiliation, need and the body" (Young, 1998: 406). Thus, in the bourgeois public sphere, the "virile subject" (Oliver, 1997: 119) of the white, bourgeois male became the repository for abstract authority, property and the law. Notions of citizenship have been patterned on the same set of assumptions: those who are deemed to have control over their bodies become full citizens, whereas those who are ruled by their bodies become lesser citizens (Bacchi and Beasley, 2002). As Lauren Berlant (1993: 176) observes: "white male privilege has been veiled by the rhetoric of the bodiless citizen, the generic "person" whose political identity is apriori precisely because it is, in theory, noncorporeal... The white, male body is the relay to legitimation, but even more than that, the power to suppress that body, to cover its tracks and its traces, is the sign of real authority, according to constitutional fashion." Concrete bodies are simultaneously suppressed and acquire a "surplus corporeality of racialized and gendered subjects" (Berlant,1993: 178). Thus, the bourgeois separation between private and public can be understood in terms of a dialectics of bodily exclusion and over-embodiment of those whose labours are the source of its material and cultural achievements. On the one hand, the abstract generality of the public sphere requires that all concrete, corporeal markers of identity be left behind; on the other, these same bodies are 'marked' by configurations of class, race and gender. ${ }^{7}$ In other words, the dialectics of embodiment present in the

${ }^{7}$ This dialectic of bodily effacement and over-embodiment is captured beautifully by Ralph Ellison in his introduction to his novel Invisible Man where he writes: "despite the bland assertions of sociologists, [the] 'high visibility' [of the African American man] actually rendered one unvisible...His darkness...glow[ing]... within the American conscience with such intensity that most whites feigned moral blindness toward his predicament" (Quoted in Gordon, 1997: 17). What Ellison's statement foregrounds is the way in which the machinery of abstraction at the heart of capitalism reifies certain forms of over-embodiment at the same time as it subsumes concrete bodies. 


\section{Multiculturalism and the Fetishism of Difference}

bourgeois public sphere may equally be seen as a mediated form of capitalism's basic social-productive relations, relations which simultaneously ascribe differential value to different types of concrete labour and deny this reality at the level market exchange through the formal appearance of equality.

If in the classical liberal public sphere it is the white, bourgeois male which lurks behind the opaque form of abstract citizenship, with multicultural citizenship a new twist presents itself: the racialized body is brought back in, only this time as a visible abstraction. Visibility functions here as a form of concealment through the relentless exposure of marked difference. Visible hyper-embodiment becomes the 'fantastic form' which conceals racism at the heart of the system; a 'phantasmagoria' of difference. The fetishism at work here is one which operates at the level of what appears to be a relation between concrete individuals but which is in fact a reified abstraction; the mystification, paradoxically, rests in the laying bare of visible difference. The "paradox of diversity," identified by Himani Bannerji takes precisely this form: "the concept of diversity simultaneously allows for an emptying out of actual social relations and suggests a concreteness of cultural description and through this process obscures any understanding of difference as a construction of power" (Bannerji, 2000: 36).

Multicultural citizenship, although not reducible to commodity fetishism, mimics and mirrors its general form. The reified forms of ethnicity and cultural difference that it sets up, however, involve a specific form of inverted reality based in a quite distinct dialectic of revelation and concealment. Multiculturalism conceals the racialization and gendering of concrete social relations behind the surface appearance of domesticated, bearable otherness: the hyper-visibility of 'visible minorities' and 'people of colour' becomes the camouflage which masks the racism at the core of capitalism - hidden, as it were, in plain sight.

Multicultural citizenship, therefore, conceals as much as it reveals. The trick is that it does this through the exposure of difference. The fetishism lies in its supposed 'unmasking' of Otherness; visibility, in this case, heightens the mystification. As Michael Taussig observes in another context, "far from demystifying, demasking can heighten the masking power of the mask" (Taussig, 1998: 231). Multicultural citizenship thus conforms to a more general paradox associated with contemporary capitalism identified by Zizek (1997b: 102):

The paradox is that - in a kind of reversal of the cliche according to which Western ideology dissimulates the production process at the expense of the final product - the production process, far from being the secret locus of the prohibited, of what cannot be shown, of what is concealed by the fetish, serves as the fetish which fascinates with its presence... The central paradox (and perhaps the most succinct definition) of postmodernity is that the very process 


\section{of production, the laying-bare of its mechanism, functions as the fetish which conceals the crucial dimension of the form, that is, the social mode of production.}

In this sense, multicultural visibility has become part of the phantasmagoria of latecapitalism where "universal visibility... is welcomed and reveled in for its own sake" (Jameson, 1998: 110). The "brightness, brilliance and vividness" (Bannerji, 2000:32) of diversity becomes allied to the general consumption of images which distinguishes contemporary commodity culture. Ultimately, this is why the 'otherness' represented in multiculturalism seems so familiar; because it has been so effectively assimilated to the commodity form. Saturated with the logic of the commodity form, multiculturalism is really a variant of what Adorno (1991: 87) called 'identity thinking' which, in this case, seeks to reduce otherness to a simulacrum of itself or alternately, expel it in a paranoid act of exclusion. As a form of 'identity thinking' it homogenizes the world whilst cleverly presenting itself as radical difference. Like the social system from which it springs, it presents the ever-same in the form of the ever-different.

The promise of citizenship in the bourgeois public sphere was that the suppression of the local body would be compensated through the acquisition of the artificial body of abstract personhood. But, as we have seen, abstract personhood was always already saturated with the presence of the white bourgeois male and the commodity form. As Lauren Berlant (1993: 200) argues: "in modern America, the artificial legitimacy of the citizen has merged with the commodity form: its autonomy, its phantasmic freedom from its own history, seem to invest it with the power to transmit its aura, its 'body' to consumers." Multiculturalism might at first appear to resolve this problem by providing those burdened by over-embodiment with some kind of release through the acquisition of artificial personhood in the multicultural state. But this too is a ruse. The marked identities which receive validation are those which correspond to the reified ethnicities of multicultural discourse which has become increasingly allied to global commodification and thus afford no escape from over-embodiment. Indeed, to the extent that the discourse of diversity fetishizes and reifies visibility, it only compounds the problem of surplus corporeality within the bourgeois public sphere.

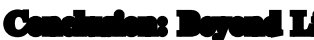

I have argued that the form of multicultural citizenship extant in many liberal-capitalist societies today, should be understood as a mediated form of capitalism's basic social relations. At the core of these relations is the duality and opposition between concrete and abstract social labour. It is in the nature of capitalism to occlude the concrete, embodied side of labour just as it is to mask the racialization and gendering of the bodies of certain groups of workers. Both of these moments are obscured at the level of everyday social 


\title{
Multiculturalism and the Fetishism of Difference
}

relations and social agents interact as ostensible equals. This is the illusory and fetishistic domain of bourgeois citizenship. Multiculturalism amplifies the fetishistic form of liberal citizenship through its own peculiar dialectic of revelation and concealment by effacing the lived experience of racism and sexism through the apparent validation of visible forms of difference.

Multiculturalism thus claims to have resolved the problem of 'difference' while, like the neurotic, it represses its own terrible secret - that beneath the veil of multicultural equality lie more systemic forms of racialization. The fetishism of multiculturalism, as with that of the commodity, involves a forgetting of origins; meanings are detached from their sources and hypostisized. Subjects are invited to invest in and define themselves in terms of these reified forms. As such, multiculturalism is an ideology of denial. It asks the oppressed to make an affective investment in the reified ethnicities it establishes and to forget those bodily memories of racism which rear up from everyday life but which now find no place in the official transcript of the public sphere. To those oppressed by racism it says, in effect, 'your difference is now acknowledged; you are part of the colourful tapestry of the nation'; and, implicitly, 'stop whining about racism'.

Like the structure of neurosis, the ideology of liberal multiculturalism adheres to a specific logic of visibility and invisibility where what is visible takes place in terms of what is hidden. As a form of ideology, it can be seen, as Eagleton (1991: 134) suggests, as a kind of "compromise formation" concealing and revealing at the same time. And just as the neurotic's visible behaviour betrays some underlying and unresolved dilemma, so too does multiculturalism both express a problem and seek its solution, however inadequate we might believe that solution to be. Like the neurotic's behaviour, the ideology of multiculturalism partakes of a certain wish-fulfillment; it contains within its core a ghostly fore-image of what might be. The multicultural fetish is therefore not an illusion in the conventional sense of a screen; rather, reality and appearance are intertwined in such a way that it contains both illusion and the purported solution to the illusion:

\begin{abstract}
To work, the ruling ideology has to incorporate a series of features in which the exploited majority will be able to recognize its authentic longings. In other words, each hegemonic universality has to incorporate at least two particular contents, the authentic popular content as well as the distortion by the relations of domination and exploitation (Zizek, 1997a: 29). ${ }^{8}$
\end{abstract}

\footnotetext{
${ }^{8}$ Eagleton (1991: 184-85) makes a similar point about the dual character of ideology: "If ideology is a condition of reality suffused and supported by our unconscious desires, as well as by our anxiety and aggression, then it conceals a utopian kernel. Illusion adumbrates within the present some more desirable state of affairs in which men and women would feel less helpless, fearful and bereft of meaning. It is thus radically double-edged, anodyne and aspiration together; and Frederic Jameson has argued that this is true of all artifacts of class society. Ideologies, cultural formations and works of art may well operate as strategic 'containments' of real contradictions; but they also gesture, if only by virtue of their collective form, to possibilities beyond this oppressive condition."
} 


\title{
Multiculturalism and the Fetishism of Difference
}

Multiculturalism thus both distorts reality and gestures toward something beyond itself. It expresses not just the fetishized abstraction of ethnic visibility but also its alter ego; the 'truth' of concrete experience and of what is 'written on the body.' It signals a disjunction between what is seen and what is known. This duality is a version of the duality of lifeprojects and meaning-making referred to earlier. It is one which expresses the 'utopian kernel' of a world free of racism and oppression and which suspects that the liberal multiculturalist solution is not all there is to the matter. Thus, on the one hand, multiculturalism represents a kind of 'spectacular' consciousness in the thrall of reified forms of ethnicity, culture and representations of the self which arise from its fetishistic form; yet it also contains intimations of its opposite, a different kind of social understanding on the part of the oppressed, which signals that everything is not quite right with the world. ${ }^{9}$

Such alternative ways of knowing are vital to the struggle against capitalist forms of oppression. As such it is a version of what some feminist theorists have called 'situated knowledge', the kind of understanding and insight that arises from a particular perspective or vantage point. As Dorothy Smith (1999: 126-27) argues:

\begin{abstract}
Knowledge is not the product of the solitary Cartesian consciousness, nor is it contained within a discursive field. Sense, meaning, truth - and falsehood - are always the local achievements of people whose coordinated and coordinating activities bring about a connectedness of statements about the world and the world they index during that time, in that place, and among those who participate in the social act, whether present or not.
\end{abstract}

Situated knowledge should not be confused with the subjective or relativistic. To say that something is 'true' - from whatever vantage point or process we may have arrived at it is simply to say that its opposite cannot also be true at the same time. As Eagleton (2003: 106) observes:
All truths are established from specific viewpoints; but it does not make sense to say that there is a tiger in the bathroom from my point of view but not from yours. You and I may contend fiercely about whether there is a tiger in the bathroom or not. To call truth absolute here is just to say that one of us has to be wrong.

Situated knowledge is thus not the enemy of truth but its ally. Marx believed that the bourgeoisie was blinded by its class interests from grasping the secret behind the commodity form. The standpoint of the oppressed and exploited, as Lukacs understood though he tended to conflate truth with class position or standpoint - carries with it its own practical forms of knowledge and insight (Lukacs, 1975). Such ways of knowing and

\footnotetext{
${ }^{9}$ For an extended discussion of such alternative forms of understanding see Gordon (1997).
} 


\section{Multiculturalism and the Fetishism of Difference}

perceiving the world arise out the struggles of the oppressed and exploited to rescue some of the sentient, embodied forms of experience for themselves. To say that those who suffer the depredations of racism and exploitation are in a 'position to know' is simply to acknowledge that this vantage point reveals certain truths about the way in which the system operates which are not open to their oppressors (Eagleton, 2003: 135-36). It is a way of knowing - embodied and situated - which signals the return of that which material relations and ideology have conspired to repress. What returns may yet be only that ghostly fore-image of a society free from oppression and exploitation. Nonetheless, such ways of knowing and seeing are the constellations out of which new worlds are built. 
Adorno, T. 1991. "The Culture Industry Revisited.” In The Culture Industry: Selected Essays on Mass Culture. J.M. Bernstein (ed.). London: Routledge, pp. 85-92.

Avrill, G. 1996. "Global Imaginings.” In Making and Selling Culture. R. Ohman (ed.). Hanover: New England University Press, pp. 203-223.

Al-Azmeh, A. 1996. Islams and Modernities. London: Verso.

Bacchi, C.L. and C. Beasley. 2002. "Citizen Bodies: Is Embodied Citizenship a Contradiction in Terms.” Critical Social Policy, Vol. 22, No. 2, pp. 324-352.

Bannerji, H. 2000. The Dark Side of the Nation: Essays on Multiculturalism, Nationalism and Gender. Toronto: Canadian Scholar's Press.

Bannerji, H. 1995. "The Passion of Naming: Identity, Difference and the Politics of Class." In Thinking Through: Essays on Feminism, Marxism and Anti-Racism. Toronto: The Women's Press, pp. 17-39.

Banerjee, S.B. and S. Linstead. 2001. "Globalization, Multiculturalism and Other Fictions: Colonialism for the New Millennium?” Organization, Vol. 8, No.4, pp. 683-722.

Berlant, L. 1993. "National Brands/National Body: Imitation of Life." In The Phantom Public Sphere. B. Robbins (ed.). Minneapolis: University of Minnesota Press, pp. 173-208.

Blackburn, R. 1988. The Overthrow of Colonial Slavery. London: Verso.

Bonefeld, W. 1995. "Money, Equality and Exploitation: Interpretation of Marx's Treatment of Money." In Global Capital, Nation States and the Politics of Money. W. Bonefeld and J. Holloway (eds.). London: St. Martin's Press, pp. 178-209.

Bonefeld, W., Gunn, R. \& K. Psychopedis. 1992. Open Marxism Volume II. London: Pluto.

Bonefeld, W., Gunn, R.\& K. Psychopedis. 1995. Open Marxism Volume III. London: Pluto. 


\section{Multiculturalism and the Fetishism of Difference}

Clarke, S. 1991. The State Debate. London: MacMillan.

Costa, J.A. 1995. Marketing in a Multicultural World: Ethnicity, Nationalism, and Cultural Identity. Thousand Oaks, California: Sage Publications.

Das Gupta, T. 1996. Racism and Paid Work. Toronto: Garamond Press.

Day, R. 2000. Multiculturalism and the History of Canadian Diversity. Toronto: University of Toronto Press.

Eagleton, T. 1991. Ideology. London: Verso.

Eagleton, T. 2003. After Theory. London: Allen Lane.

Fine, B. 1986. Democracy and the Rule of Law. London: Pluto Press.

Fraser, N. 1996. "Rethinking the Public Sphere: A Contribution to the Critique of Actually Existing Democracy." In Habermas and the Public Sphere. C. Calhoun (ed.). Cambridge Massachusetts: MIT Press, pp. 109-142.

Gordon, A. 1997. Ghostly Matters: Haunting and the Sociological Imagination. Minneapolis: University of Minnesota Press.

Guillaumin, C. 1999. “I Know it's Not Nice But ...' The Changing Face of Racism.” In Race, Identity, and Citizenship: A Reader. R. Torres, L.F. Miron and J.X. Inda (eds.). Oxford: Blackwell Publishers, pp. 39-46.

Halter, M. 2000. Shopping for Identity: The Marketing of Ethnicity. New York: Schocken Books.

Harvey, D. 2000. Spaces of Hope. Berkeley: University of California Press.

Holloway, J. 2002. Change the World Without Taking Power. London: Pluto.

Holton, R.J. 2000. "Multiculturalism: The Politics and Poetics of Public Space." In Democracy Citizenship and the Global City. E.F. Isin (ed.). London: Routledge, pp. 189-202.

Horkheimer, M. \& T. Adorno. 1972. Dialectic of Enlightenment. New York: Continuum. 
http://www.diversity.com.html. Accessed August 21st, 2004.

Jameson, F. 1998. The Cultural Turn. London: Verso.

Klein, N. 2000. No Logo: Taking Aim at the Brand Bullies. Toronto: Vintage Canada.

Koundoura, M. 1998. "Multiculturalism or Multinationalism?" In Multicultural States: Rethinking Difference and Identity. D. Bennet (ed.). London: Routledge, pp.69-87.

Lebowitz, M. 1992. Beyond Capital. New York: St. Martin’s Press.

Lukacs, G. 1975. "Reification and the Consciousness of the Proletariat." In History and Class Consciousness. Cambridge, Massachusetts: MIT Press.

Marx, K. 1977. Capital. Volume One. Translated by B. Fowkes. New York:Vintage Books.

McClintock, A. 1995. Imperial Leather. London: Routledge.

McNally, D. 2001. Bodies of Meaning. Albany: SUNY Press.

McNally, D. 2004. "The Dual Form of Labour in Capitalist Society and the Struggle Over Meaning: Comments on Postone." Historical Materialism, Vol. 12, No. 3, pp. 189-208.

Miles, R. \& M. Brown. 2003. Racism. Second Edition. London: Routledge.

Miles, R. and R. Torres. 1999. "Does 'Race'Matter? Transatlantic Perspectives on Racism and 'Race Relations'.' In Race, Identity, and Citizenship: A Reader. R. Torres, L.F. Miron and J.X. Inda (eds.). Oxford: Blackwell Publishers, pp. 19-38.

Mooers, C. 2001. "The New Fetishism: Citizenship and Finance Capital." Studies in Political Economy, Vol. 66, pp. 59-84.

Oliver, K. 1997. Family Values. London: Routledge.

Ong, A. 1999. "Cultural Citizenship and Subject Making: Immigrants Negotiate Racial and Cultural Boundaries in the United States." In Race, Identity and Citizenship: A Reader. R. Torres, L.F. Miron and J.X. Inda (eds.). Oxford: Blackwell Publishers, pp. 262-293. 


\section{Multiculturalism and the Fetishism of Difference}

San Juan, E. 2002. Racism and Cultural Studies. Durham, North Carolina: Duke University Press.

San Juan, E. "Marxism and the Race/Class Problematic: A Re-Articulation." http://eserver.org/clogic/2003/sanjuan.html . Retrieved 27/10/03.

Sears, A. 2003. Retooling the Mind Factory: Education in a Lean World. Toronto: Garamond Press.

Smith, D. 1999. Writing the Social. Toronto: University of Toronto Press.

Stallybrass, P. 1998. "Marx's Coat.” In Border Fetishisms: Material Objects in Unstable Spaces. Patricia Spyer (ed.). London: Routledge, pp. 183-207.

Taguieff, P.A. 2001. The Force of Prejudice. Minneapolis: University of Minnesota Press.

Taussig, M. 1993. Mimesis and Alterity: A Particular History of the Senses. London: Routledge.

Taussig, M. 1998. "Crossing the Face." In Border Fetishisms: Material Objects in Unstable Places. Patricia Spyer (ed.). New York: Routledge, pp. 224-244.

Young, I.M. "Polity and Group Difference." In Feminism and Politics. Anne Philips (ed.). Oxford: Oxford University Press, pp. 401-429.

Wood, E.M. 1995. Democracy Against Capitalism. Cambridge: Cambridge University Press.

Zizek, S. 1997a. "Multiculturalism, Or, the Cultural Logic of Multinational Capitalism." New Left Review, Vol. 223, pp. 28-51.

Zizek, S. 1997b. The Plague of Fantasies. London: Verso.

Zizek, S. 2002. Welcome to the Desert of the Real. London: Verso. 